\title{
MIGRATION AND CHANGING POOR DYNAMICS IN A VILLAGE: A CASE STUDY
}

\author{
Harasankar Adhikari, Researcher \\ Monihar Co.H. Society, India \\ Phone: 9748031763, E-mail: jaoya123@yahoo.co.in
}

\begin{abstract}
The urbanization has been significantly created wide scope of employment opportunities through manifold services sector. The mobility or migration of rural people has changed the social and economic condition of the landless labour of the rural area. In this case study migration of the village young of East Midnapore district of West Bengal who were from landless labour families with a little education has been noted. Their social and economic position had been remarkably changed within 3-5 years. They were capable to make their family healthy and wealthy through improved shelter, regular diet and creation of other properties.
\end{abstract}

\section{KEY WORDS}

Urbanization; Migration; Village young; Landless labour.

The villages of India are its heart and according to the last report bank $69.90 \%$ of the population is living in the villages/rural area of India. The Census of India's 2011 Provisional Population has stated that of the 121 crore Indians, 83.3 crore live in rural areas while 37.7 crore stay in urban areas. But the rapid urbanization indicates that urban population has increased from 27.81 per cent in the 2001 Census to 31.16 per cent in the 2011 Census, while the proportion of rural population declined from 72.19 per cent to 68.84 per cent because of The slowing down of the overall growth rate of population is due to the sharp decline in the growth rate in rural areas, while the growth rate in urban areas remains almost the same.

The most disquieting features of the rural economy of India are traditional village farming, modern agriculture, handicrafts and other some (fishing, forest resources) depending on its geographical location. The most of the rural population is generally considered as agriculture labour. They get unusually low wages for the work done under the worst conditions put in excessively burdens on hard work (Robert L. Hardgrave, 2008). The opportunity to work is extremely irregular; hence their income is also low. Since, they possess no skill or training, they have no alternative employment opportunities either and their economic lot has failed to improve even after four decades of developmental efforts. Hence, the problems of agricultural labour are manifold and are mainly centered round the basic problems of rural economy which include low income, low productivity and lack of continuous employment. Among them the landless and the small landowners constitute almost $60 \%$ population of the rural household. Landless labourers tend to compromise a higher proportion of the rural sector in West Bengal (34-73\% of the rural population) (Robert L. Hardgrave, 2008). They generally work on annual or seasonal basis and they work on some sort of contract. Their wages are determined by custom or tradition. On the other hand, temporary or casual labourers are engaged only during peak period for work. Their employment is temporary and they are paid at the market rate. Further it has been seen that surplus workforce in agriculture and inadequate job opportunity in industrial sector are also significant for their daily survival (Robert L., 2008). As consequence of this they are mostly out of the development and progress as desired in the context of global economy. Their housing condition and social status including poor health, rate of school dropped out are comparatively indicate their situation as traditional their village life.

But the urbanization is synonymous with growth, development and modernization of a country in general and services sector in particular. Increasing share of services sector and declining share of agriculture in GDP of an economy is a sufficient indicator of structural change indicating development. A rural or backward area gradually gets urbanized with provision of certain basic infrastructures like mettle roads, drinking water, electricity, 
telecommunication, drainage and sewerage, pucca houses etc. There exists both positive and negative correlation between urbanization and socio-economic consequences. On the positive side, urbanization promotes growth of the services sector - trade and commerce, transport and communication, real estate, hotels and tourism and construction activities, thereby creating job opportunities and so on. It has created a wide scope to suck up a vast majority of rural population as unskilled workers (Gowda \& Subrahamanya, 2003).

Babalpur, a Hindu village of East Midnapore district of West Bengal is typical in its character. It is located near by to the district head quarter, Tamluk. It is well connected with other parts of the district by roadways. In the north of the village the 'sadak' road has blown and connected to the National Highway no-34 in one part and other part it is connecting to the Moyna Basin of the district. Obviously the people of so-called higher classes and castes who are financially well equipped are residing at the side of the road and it is considered as the front side of the village and the Scheduled castes/lower caste people are in the backside of the village. About 1852 population is in the village and evidently the male and female ratio is almost equal and out of which around 452 is belonging to SCs and OBCs. Interestingly about $30 \%$ of the population is illiterate or just literate who are above 50 years of age. Of these $60 \%$ of the population is female. At present there is no non-school going or dropped out at least upto Secondary education and interestingly the lower castes people are in progress for higher education irrespective of gender of the population. The economy of the village is based on agriculture (paddy, bittle nut cultivation and handicrafts). About $80 \%$ of the population including female depends on agriculture and handicrafts, $12 \%$ is as transport workers. $6 \%$ is locally available jobs. Only $2 \%$ is in service sector who belong to so-called higher class. The growing generation especially from the higher class or economically rich is in their higher education and they are outside the villages for fulfillment of their desired goal of a service. On the other hand a vast majority of the both male and female population of the agriculture or economically poor has no scope of their higher education because of their financial support while they are lack in their daily needs. Firstly they search for locally available jobs and in absence of this they are migrating into urban area, out side of the state as unskilled labour.

Here the changing social and economy status of this younger generation has been studied. During last 5 years (2005-2010) about 25 males of $16-20$ years of age were migrated to Mumbai and Banglore for their job and they were entered into the trade of jewelry works. They were from the family of landless labor and belonged to the family where their minimal self was questioned. The study has been recorded their all round progress and development. For this purpose an interview schedule and discussion were conducted with them and their family's members.

Social and cultural milieu of the younger before their migration. We find that the migrated younger were generally males of 16-20 years of age with unmarried marital status . They were socially dominated by backward community (Table 1) and out of $64 \%, 28 \%$ were belonging to SCs and 36\% was from the Other Backward Classes. Educationally the general categories were more advanced than the backward community and they had covered their education upto classVIII which was $24 \%$ and $4 \%$ was Madhyamik passed. While $28 \%$ of them had experience of primary education and all of them was from backward community and $18 \%$ of them was upto Class VIII. Lastly $8 \%$ was within the standard of IX-X.

Table 1. Social and educational background of the younger

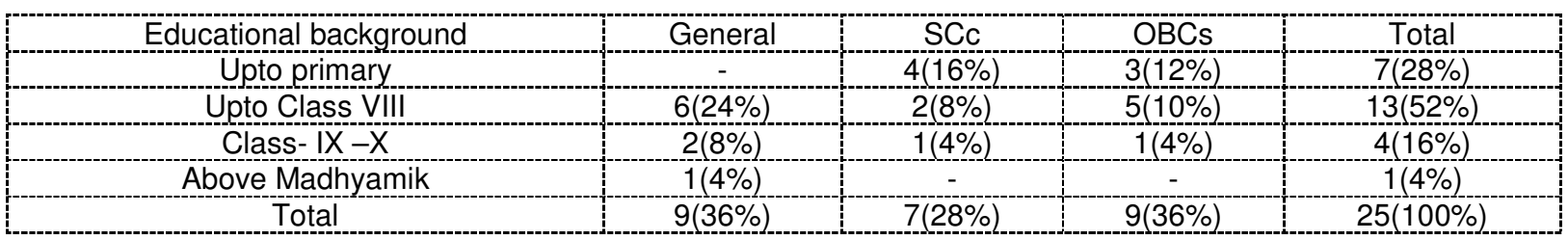

From the Table 2 the family size of the migrant younger describes that $28 \%$ of them (25 members) was of nuclear family meant their parents and minor siblings were living 
together. While $40 \%$ of them who had $6-8$ members was living with grand parents and other kins of their family and $32 \%$ of their family (more than 8 members) was under same category and their parents were not followed the norms of small family.

Table 2. Family size and Family income of the respondents

\begin{tabular}{|c|c|c|c|c|}
\hline \multirow{2}{*}{ Family income per month } & \multicolumn{3}{|c|}{ Number of Family members } & \multirow{2}{*}{ Total } \\
\hline & $2-5$ members & 6-8 Members & More than 8 members & \\
\hline$<$ Rs. 1000 & $3(12 \%)$ & $2(8 \%)$ & $2(8 \%)$ & $7(28 \%)$ \\
\hline Rs. $1001-1200$ & $2(8 \%)$ & $6(24 \%)$ & $2(8 \%)$ & $10(40 \%)$ \\
\hline Rs. $1201-1500$ & $1(4 \%)$ & $1(4 \%)$ & $2(8 \%)$ & $4(16 \%)$ \\
\hline$>$ Rs. 1500 & $1(4 \%)$ & $1(4 \%)$ & $2(8 \%)$ & $4(16 \%)$ \\
\hline Total & $7(28 \%)$ & $10(40 \%)$ & $8(32 \%)$ & $25(100 \%)$ \\
\hline
\end{tabular}

Comparing the Table 2 \& 3, 40\% of their family's earning was within Rs.1001-1200/per month from agricultural daily labour (34\%) and $8 \%$ was weavers while another $8 \%$ was earned from other sources. In that case $32 \%$ had their double earning members. $16 \%$ of them earned Rs. 1201- 1500 per month and they had double earning members in their family. Only $16 \%$ of these families earned more than Rs.1500 per month where $8 \%$ had at least 3 earning members. So, it had been seen that the wages in agriculture and weaving were low to meet the basic needs of their families. Within their village and outside their villages there was no such source of earning from where they could earn a healthy from their wages. Secondly there were no rules and restriction and its monitoring regarding fixation of the wages.

Table 3. Earning members in their family income and nature of engagement

\begin{tabular}{|c|c|c|c|c|c|c|c|c|c|c|}
\hline \multirow[b]{3}{*}{$\begin{array}{l}\text { Family income per } \\
\text { month }\end{array}$} & \multicolumn{9}{|c|}{ Number of members and their engagement } & \multirow[b]{3}{*}{ Total } \\
\hline & \multicolumn{3}{|c|}{ Single member } & \multicolumn{3}{|c|}{ Two members } & \multicolumn{3}{|c|}{ More than two } & \\
\hline & 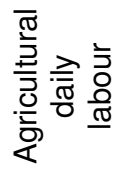 & 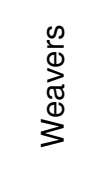 & $\begin{array}{l}\frac{\omega}{\Phi} \\
\frac{\Phi}{ \pm}\end{array}$ & 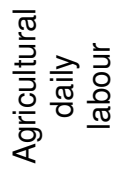 & 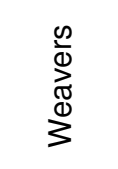 & $\begin{array}{l}\frac{\omega}{\Phi} \\
\frac{1}{ \pm}\end{array}$ & 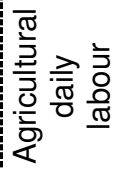 & $\begin{array}{l}\frac{\infty}{\infty} \\
\stackrel{\infty}{\infty} \\
3\end{array}$ & & \\
\hline$<$ Rs. $1000 /-$ & $4(16 \%)$ & $2(8 \%)$ & $1(4 \%)$ & - & - & - & - & - & - & $7(28 \%)$ \\
\hline Rs. $1001-1200 /-$ & $2(8 \%)$ & - & - & $4(16 \%)$ & $2(8 \%)$ & $28 \%$ & - & - & - & $10(40 \%)$ \\
\hline Rs. $1201-1500 /-$ & & & 5 & $28 \%)$ & $2(8 \%)$ & & 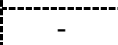 & - & - & $4(16 \%)$ \\
\hline$>$ Rs. $1500 /-$ & & & & $1(4 \%)$ & $1(4 \%)$ & & $2(8 \%)$ & - & - & $4(16 \%)$ \\
\hline Total & $6(24 \%)$ & $2(8 \%)$ & $1(4 \%)$ & $7(28 \%)$ & $5(20 \%)$ & $2(8 \%)$ & $2(8 \%)$ & - & - & $25(100 \%)$ \\
\hline
\end{tabular}

Living condition of these families. The shelter or housing of these families was small and dense usually constructed from mud blocks, roofs are thatched and the floors are covered with a mud and cow-dung paste that serves as a disinfectant. These had been built in their inherited plot of land(vastu) measuring hardly 2-3 kathas consisting only single room with either side of narrow lanes(vernada). The kitchen was also attached with one 'vernada'. No bathroom and toilet as well as sanitary measures were in their house. Generally they had to us the bushes or open land for their daily purpose and ponds water for their daily activities. Only the tube well water was used as drinking purpose.

Their dietary provision including daily foods was managed typically where the female usually used to collect some vegetables from their locality or which they were cultivated. The senior member's especially grand father used to fishing from the common vested ponds or canal located at the side of their villages. So, their nutrition and diet were managed anyway.

The health care system was mostly managed by their self traditional sense from medicinal plants and in any emergency they generally visited the local quack because of not only their poor economy, the Govt. health care facilities were not within $20 \mathrm{kms}$ of the village.

The education of their children was managed in anyway and they had not got any material support or little support provided by some well wishers. Their self interest was a mode of help to continue their education. 
In their daily life there was no relaxation or other infrastructural facilities beyond some cooking utensils.

Changing scenario in their living standard after migration of one member from a family. The younger were migrated for unskilled job outside the state of West Bengal at Mumbai and Banglore city with their relative/known agent. Firstly for 2-3 months they worked as apprentice in jewellery industry with a monthly wages only to manage themselves. After three months they worked as skilled labour with handsome monthly payment alongwith other facilities of overtime, bonus and so forth. Then they were shared their earning with their family at maximum for care of their family. The following changes were occurred in their family in 1st phase:

- The members were got two square meals with healthy dietary measures;

- They facilitated their health care with modern facilities;

- They facilitated younger siblings education with proper measures and supports;

- The marriage ceremony of their elder sisters.

In 2nd phase they looked for their shelter with sanitary provision so that they promoted to develop their pacca house with concrete roof including attached toilet and bathroom. Then electrification of their house and infrastructure, i.e. television and other necessary arrangement were cherished.

Thereafter their trend was to focus on saving through recurring and insurance with purchasing of gold ornaments and land also. The table 4 analyses that the creation of properties (movable and immovable) depends on the tenure of involvement in their jobs after their migration. Among the young(40\%) who had in $2-3$ years in their job, $4 \%$ had owned more than $1 / 2$ bigha of land, $20 \%$ had built their pacca house and $4 \%$ each was the insurance and saving holder and other assets respectively. On the other hand $8 \%$ had in well position to create all the above properties within 2-3 years of their involvement in jobs.

Table 4. Property own after migration according to their duration in work place

\begin{tabular}{|c|c|c|c|c|c|c|}
\hline \multirow[b]{2}{*}{$\begin{array}{c}\text { Duration of } \\
\text { migration }\end{array}$} & \multicolumn{5}{|c|}{ Property own (both movable and immovable } & \multirow[b]{2}{*}{ Total } \\
\hline & $\begin{array}{l}\text { Land owned } \\
\text { (more than } 1 / 2 \\
\text { bighas) } \\
\text { (1) }\end{array}$ & $\begin{array}{l}\text { Pacca } \\
\text { House(two } \\
\text { stored) } \\
\text { (2) }\end{array}$ & $\begin{array}{l}\text { Insurance and } \\
\text { other saving } \\
\text { (3) }\end{array}$ & $\begin{array}{l}\text { Other } \\
\text { assets } \\
(4)\end{array}$ & $\begin{array}{c}\text { All } \\
(1+2+3+4)\end{array}$ & \\
\hline $2-3$ years & $1(4 \%)$ & $5(20 \%)$ & $1(4 \%)$ & $1(4 \%)$ & $2(8 \%)$ & $10(40 \%)$ \\
\hline 3- 5 years & $2(8 \%)$ & - & - & - & $13(52 \%)$ & $15(60 \%)$ \\
\hline Total & $3(12 \%)$ & $5(20 \%)$ & $1(4 \%)$ & $1(4 \%)$ & $15(60 \%)$ & $25(100 \%)$ \\
\hline
\end{tabular}

But the young $(60 \%)$ who was in 3-5 years of involvement in their jobs was financially in better position expect $8 \%$ of them who had only able to own $1 / 2$ bigha of land, while $52 \%$ of them had been owned more than $1 / 2$ bigha of land, pacca house with insurance and saving as well as other assets for their domestic purpose.

Education of the younger siblings. From the study it was assessed that $60 \%$ of their younger siblings had completed their $10+2$ and out of which $40 \%$ was their sisters. Among them $20 \%$ was in their college education and rest of their siblings was under the high school education.

Changing social position in their village. It was noted when their families were in economically week, they were only treated as poor in any social function in the village. Even their opinion was not respected in village sansad led by the Panchayat member. The socalled well equipped villagers used to dominate the decision. Firstly this population was their daily labour and they showed their kindness as their servant only. But surprisingly when their economic position was gradually in changing trend which was physically verified, their families' importance was changed. They were getting importance and participating in the village common festival and village meeting also. They also left their daily labour jobs and the children were in well performance in their school. The overall situation has brought a new Diaspora in their life. 
Conclusion. India is dominated by villages and villagers. It's development is villages centric. But in the era of globalization villages are economically in an adverse situation due to low agricultural productivity and other economic sources are also in a stagnant position because of non-sustainability in the present market and marketing system. In villages a high percentage of population are landless labour and they are in socially and economically in backward situation. Due to this their younger generation is deprived proper care and attention in all terms. Again the agricultural surplus labour and unemployment have been added for their adverse situation where survival with minimal self is a question. But the growth and development of urbanization has helped to create various opportunities in services sector which engulfs even the unskilled and low educated youth. As a consequence the rate of migration of rural population has been increased.

In the present case study of village has been shown that the migration of 25 young of 16-25 years age into Mumbai and Banglore had changed their social and economic status within 3-5 years. From their landless labour background they had established themselves and their family in a healthy and wealthy condition. They were capable to built up their dream in life. All of them had been capable to reconstruct their shelter and their daily life with all better prospect and majority (64\%) of them had owned at least $1 / 2$ bigh of land of their own. Their younger siblings education and other domestic occasion were the significant change to break their vicious cycle of poor. The magnitude of their changes had been interestingly noted when their families were sharing their decision in village festivals or in village sansad meeting. So, the urbanization and its scope has been given immense opportunities to the young of lower group to come out from their traditional living through their purposeful mobility towards urban area. It is an positive impact of urbanization needed more to change their village economy.

\section{REFERENCES}

[1] The Census Report of India, 2011, Govt. of India, New Delhi.

[2] Gowda, M.V. Srinivas \& Susheela Subrahamanya(2003), Infrastructure Development for Economic Growth, Deep \& Deep Publications, New Delhi.

[3] Robert L. Hardgrave, JR and Stanley A Kochanek (2008), India: Government and Politics in a Developing Nation, Thomson Higher Education: Boston, USA. 